\title{
Pop Culture as Argument and Aspiration
}

\author{
Richard Fox \\ Department of Pacific and Asian Studies, University of Victoria \\ rpfox@uvic.ca
}

\begin{abstract}
The scholarship on post-authoritarian Indonesia has taken a relatively passive attitude to theorizing popular culture-either presupposing the category absolutely, or invoking prior theorists as authorities without querying the coherence or applicability of their accounts and terminology. As the contributions to this special issue mean to suggest, the question of popular culture may require more careful considerationnot least given its alleged importance for our understanding of recent developments in politics, religion and the economy. This introductory essay provides a brief synopsis of the articles and a survey of the key issues addressed.
\end{abstract}

\section{Keywords}

Indonesia - pop culture - media - critical theory - argument

Popular culture has figured prominently in the scholarship on post-authoritarian Indonesia, seen to affect everything from party politics and the economy to romance and religion. ${ }^{1}$ Alongside publications that aim to provide a survey of the field, an extensive literature has developed around more detailed analyses of television, cinema, fashion, pop music, street art, and social media, among other things. ${ }^{2}$ An important subset of these studies has focused on

1 The articles collected in this special issue were originally presented at the Annual Meetings of the American Academy of Religion (November 2018, Denver, CO), at a panel discussion entitled 'Pop Culture as Argument: Contesting Religion, Gender and Romance in Contemporary Indonesia'.

2 A critical review of recent publications is presented in my contribution to this issue, in the section entitled The Idea of Popular Culture. 
the intersection with Islam, highlighting the complex relationship between piety, entertainment, style, and consumption. This is arguably one of the more dynamic fields in Indonesian studies today. Yet, for all its ethnographic and analytic richness, and with but a few notable exceptions, ${ }^{3}$ this rapidly growing body of scholarship has tended to take the concept of 'popular culture' for granted-as if the term's referent were self-evident, and its theorization unproblematic. Put another way, it might be said that the scholarship on post-authoritarian Indonesia has taken a relatively passive attitude to theorizing popular culture-either presupposing the category absolutely, or invoking prior theorists as authorities without querying either the coherence or applicability of their accounts and terminology. As the contributions to this special issue aim to suggest, the question of popular culture may require more careful consideration-not least given its alleged importance for our understanding of recent developments in politics, religion, the economy, and so on.

In the first of the three articles, 'A political dance in the rain', Rosalia Namsai Engchuan explores how queer cinematic practice has disrupted a wider 'climate' of homophobia and oppression. Despite the reform movement's progress in fighting for individual freedom, LG BT Indonesians are regularly subjected to abuse, and in practice do not have equal access to the fundamental protections putatively assured by law. The rise of nationalist homophobia in the late 199os (Boellstorff 2004) and its subsequent re-articulation under the aegis of Islamic piety (Thajib 2015) have fuelled what Engchuan and others have described in terms of a 'moral panic' - as manifest in public debate, but also in violent protest and bodily attack. Under the circumstances, it has become extremely difficult-and often dangerous - to discuss openly the day-to-day forms of discrimination suffered by LGBT Indonesians. For many, the organized and aggressive support for a pious hetero-nationalism has foreclosed the possibility of resistance. Either one is a good Muslim or one is queer, but never the twain shall meet-or so the argument often goes. Facing such a seemingly intractable predicament, Engchuan describes how queer cinema has intervened to challenge this disarticulation of queer voices - and quashing of queer livesby opening up possibilities for discussion and argument. Queer films, she says, offer more than a mere 'alternative'. As arguments, they 'nullify' the prevailing 'LGBT/Islam binary'. Using the example of a short film entitled On Friday noon, Engchuan explores the rhetorical strategies—visual and verbal, aural and otherwise - that community filmmakers deploy to 'evoke empathy' and spur discussion. Engchuan has no illusions about the relative impact these small-

3 See, for example, Heryanto 2014; Hobart 2008; Jurriëns 2011. 
scale interventions may have on the 'wider public sphere'. But she convincingly shows how the performative 'nullification' of religio-nationalistic homophobia can bring hope. The weather may be terrible - and the climate inhospitablebut community filmmakers in Indonesia are out dancing in the rain, opening up spaces to imagine and work toward a better future.

Developing a closely related set of issues, Andrea Decker presents a richly complex account of gender, power, and performativity in the popular musical genre of dangdut, tracing the transformation of public debate that has accompanied dangdut's ongoing journey from village-level entertainment to nationally televised extravaganza. Her account is at once historical and ethnographic, drawing on a combination of media analysis and extensive ethnographic fieldwork - all with an eye to Indonesia's shifting articulations of sexuality, piety, and nation. Decker describes how female dangdut singers performing along the coastal Pantura Highway were — and indeed still are — admired for their ability to attract large and enthusiastic audiences-reflecting, on her account, a traditionally Javanese conception of power. It was precisely this power to attractand, more specifically, the ability to elicit an irresistibly erotic response- that animated public debates over dangdut from the late 199os through to the early 200os - as exemplified by 'Inul-mania', the controversy surrounding Inul Daratista and her 'drilling' dance (see Faruk and Aprinus 2003; Weintraub 2008). In more recent years, it seems the debate has shifted with the growing prominence of dangdut on national television. Where the sexual power of women's bodies was previously said to endanger public morality, male performers are now sharing the burden of expectation. As Decker notes, live dangdut shows have historically accommodated — and thrived upon — the sort of gender-bending ambiguity and non-normative sexuality from which Indonesian performative traditions have long derived both humour and entertainment. But, she argues, the same cannot be said for national television, where ratings-minded producers endeavour to create programmes suitable for middle-class consumption, as informed by the Indonesian Broadcasting Commission's prohibition on effeminate self-presentation for men-proscribing everything from the male use of women's clothing, make-up, and mannerism to female terms of address. It is in facing such proscriptions, and the threat of public disapproval, that many male dangdut performers have adopted Arabic-inflected lyrics and Islamically themed styles of self-presentation in order to appear heteronormatively cowok banget ('super manly') - perhaps especially when their off-screen lives may suggest otherwise. Ironically, given the Broadcast Commission's commitment to protecting gendered minorities, the ban on public male effeminacy has resulted in transgender women and other gendered minorities being hidden for their own protection'. 
Taken together, the analyses from Engchuan and Decker highlight the complex relationship between piety, gender, and nation in post-authoritarian Indonesia. They additionally draw attention to how fine-grained ethnographic and historical research may challenge prevailing understandings of large-scale processes that are conventionally described under the rubrics of globalization, Islamization, and commercialization. Inspired by these and related issues, my own contribution examines the underlying theoretical foundations for scholarly commentary on Indonesian media and popular culture, with a special emphasis on depictions of piety, class, and romance. Reflecting critically on a series of films and YouTube videos, I have tried to draw attention to some of the difficulties entailed in our unreflective reliance on notions such as 'the public sphere', 'mediascapes', and 'the marketplace of ideas'. My central contention is that, albeit convenient, the use of these terms - and the lines of enquiry they embody - help to underwrite an otherwise inexplicable leap from the analyst's own 'reading' of films, pop songs, and the like to broader statements about society as a whole. The upshot is that, in adopting such an approach, scholarship exempts itself from the theories of representation that it presumes to impose on Others-holding itself apart, as if it were able to refer objectively to a sociological reality that pop culture can but simulate, and with reference to which it may be contextualized. Drawing on a series of recent symposia on the theme of How Indonesians argue, ${ }^{4}$ I have provisionally suggested we approach popular culture in terms of argument, construed broadly as an effort to address, rebut, persuade, exemplify, or otherwise performatively transform the world and one's place within it. Among the other advantages of such an approach, this may help to level the playing field, subjecting scholarship — as itself a form of argument - to the same theoretical framing that we envisage for our popculturally imagined Others.

Implicit in this approach is the idea that an important aspect of pop culture is its orientation to the future - exemplifying aspirations that may be variously emulated, decried, or ignored in the day-to-day practices of envisaging and working toward a better life. Engchuan has shown how queer cinema embodies a critique of existing homophobia and discrimination but at the same time projects us forward to an idealized time yet to come-when LG BT Indonesians gain equal recognition as citizens and members of the various overlapping communities they help to constitute. Meanwhile, as queer cinema has leaned forward, striving to actualize a new and inspiring future, Decker describes a

4 An overview of themes and presentations is available online here: www.criticalia.org/sympo sia--panels/how-indonesians-argue.html. 
contrasting scene in which dangdut performers trace a more defensive lineworking to forestall condemnation for appearing inadequately 'manly', and so inadequately Indonesian. In so doing, they are working to garner popular support, and so succeed as performers in a crowded and unforgivingly competitive field. It is in this respect that both queer cinema and televised dangdut are directed to realizing a particular vision for the future. Yet, as a form of argument, the same may be said mutatis mutandis of scholarship. It, too, is an aspirational practice oriented to transformation. The question is, what sort of future does our work aspire to? And what sort of intellectual practice is best suited to that end?

\section{References}

Boellstorff, T. (2004). 'The emergence of political homophobia in Indonesia: Masculinity and national belonging', Ethnos:Journal of Anthropology 69-4:465-86.

Faruk and S. Aprinus (2003). Hanya Inul. Yogyakarta: Pustaka Marwa.

Heryanto, A. (2014). Identity and pleasure: The politics of Indonesian screen culture. Singapore: NUS Press.

Hobart, M. (2008). 'Introduction: Why is entertainment television in Indonesia important?', in: M. Hobart and R. Fox (eds), Entertainment media in Indonesia, vii-xv. London and New York: Routledge.

Jurriëns, E. (2011). 'A call for media ecology: The study of Indonesian popular culture revisited', Indonesia and the Malay World 39-114:197-219.

Thajib, F. (2015). 'Living in a state of suspension: Emotional dimensions of normative violence towards Indonesian queers in Islamic legal discourse', Kyoto Review of Southeast Asia 18. https://kyotoreview.org/issue-18/normative-violence-towards -indonesian-queers/.

Weintraub, A. (2008). '“Dance drills, faith spills": Islam, body politics, and popular music in post-Suharto Indonesia', Popular Music 27-3:367-92. 